\title{
CARBON (II) MONOXIDE AS A SUBJECT FOR POISONS STUDYING OF STUDY ON DISCIPLINE TOXICOLOGICAL CHEMISTRY (CRIMINAL ANALYSIS) AT THE PHARMACEUTICAL DEPARTMENT OF THE NATIONAL MEDICAL UNIVERSITY IN UKRAINE
}

\author{
Yaroslav Tsekhmister ${ }^{1}$, Elena Welchinska ${ }^{2}$
}

\begin{abstract}
Toxicological Chemistry (or Analytical Toxicology) is a field among other pharmaceutical disciplines that investigates the characteristics of toxic substances and poisons, their actions in the human body and in the cadaver material, and the ways of segregating, qualitatively detecting, and quantitatively defining poisons and their metabolites. The aim of this article is to explain the importance of studying common chemical substances, such as carbon (II) monoxide (or charcoal gas), which is a strong poison, in this chemistry field, i.e., Toxicological Chemistry, throughout the whole educational period at the Faculty of Pharmacy of the National Medical University in Ukraine.
\end{abstract}

UDC Classification: 54.01:615 (075) DOI: http://dx.doi.org/10.12955/cbup.v4.843

Keywords: toxicological chemistry, carbon (II) monoxide, toxicity, poison.

\section{Introduction}

The development of the chemistry, chemical, and pharmaceutical industries have increased the number of pharmaceutical products and substances used in medicine and various areas of the economy. Under certain conditions, these substances can cause poisoning. Sources of poisoning may include: waste water industries that pollute water bodies; pesticides (herbicides and insecticides) for pest control of crops; soil, vegetables, and fruits; chemicals that are used in households for combating insects and rodents or in the art industry. Chemicalization of the economy leads to an increase in the number of toxic substances for forensic toxicological analysis. Toxicological Chemistry or Criminal Analysis (formerly known as 'forensic chemistry') is the science that studies methods for isolation, purification, qualitative, and quantitative determination of toxic and potent substances and their metabolites in various natural sites: biological material of animal and vegetable origin, wastes of industrial enterprises in the form wastewater, air emissions, and soil in agricultural products as described by Alexandrov \& Emelianov (1990), Bayerman (1987), Busari \& Arnold (2009), Ellenhorn (2003), Knunyants (1992). The strategic line of pharmaceutical graduates' preparation involves a complex approach used for the study of special courses. Entry into such a complex approach for education at special departments is predefined by a mandatory interdisciplinary exam in a governmental attestation of graduates. This is because future professional activities of specialists and pharmacists will deal with solving issues related to the courses (European Association for Quality Assurance in Higher Education. Helsinki, 2005; Communiqué of Conference European Ministers which responsible for higher education, 2010). The graduates should be able to perform synthesis and analyze from knowledge gained in special courses aimed at solving problems that may arise in a working situation. In connection with the tasks of modern educational processes and the increasing environmental stressors in today's world, it is essential to study toxic substances, such as, carbon monoxide, at a modern scientific level and with knowledge of related sciences.

One of the most important groups of toxic substances being studied at the toxicological chemistry is the group of substances not isolated from biological material (e.g., carbon (II) monoxide (CO), hydrogen sulfur $\left(\mathrm{H}_{2} \mathrm{~S}\right)$ ). Studying the topic starts with questions of history, application, biotransformation, toxicological properties, and methods of qualitative and quantitative analysis of the group of poisons. The study topics should start by addressing the ways carbon (II) monoxide enters the human body, the toxicological effect of this poison on the body, especially the changes in bodily functions under the influence of carbon (II) monoxide, the formation of metabolites (novel compounds of carbon (II) monoxide in the body that lead to the development of pathological changes), and the death of an individual. The action of carbon (II) monoxide on the human body is understood from the burning of carbonaceous fuel in low oxygen conditions. Carbon monoxide (CO) is produced by

\footnotetext{
${ }^{1}$ Yaroslav Tsekhmister, Bohomolets National Medical University, Kiev, Ukraine

2 Elena Welchinska, Pharmaceutical Faculty, Bohomolets National Medical University, Kiev, Ukraine, elena_wwu@ukr.net
} 
incomplete combustion of hydrocarbons and carbohydrates (wood, coal, and oil). It is commonly called 'charcoal gas'. Cases of carbon (II) monoxide poisoning from a fire have been registered with explosions in rooms from oven heating. Maximum poisoning incidents occur during the spring and winter when heaters are widely used. Accidental and intentional poisoning by exhaust fumes of cars and smoke inhalation during a fire are the second cause of $\mathrm{CO}$ intoxication. A unique source of $\mathrm{CO}$ is methylene chloride, a solvent used in removing paint. Carbon monoxide is formed from methylene chloride (incoming inhalation) during metabolism in the human liver during poisoning. Carbon monoxide enters the bloodstream in cases of poisoning by inhalation, and then, with hemoglobin, forms a sufficiently stable compound of carboxyhemoglobin (HbCO; Luznikov, 1994). The affinity of hemoglobin to carbon (II) monoxide at 200-250 times higher than that for oxygen $\left(\mathrm{O}_{2}\right)$. Human blood and muscle are poisoned with CO containing hemoglobin and its compounds (Table 1).

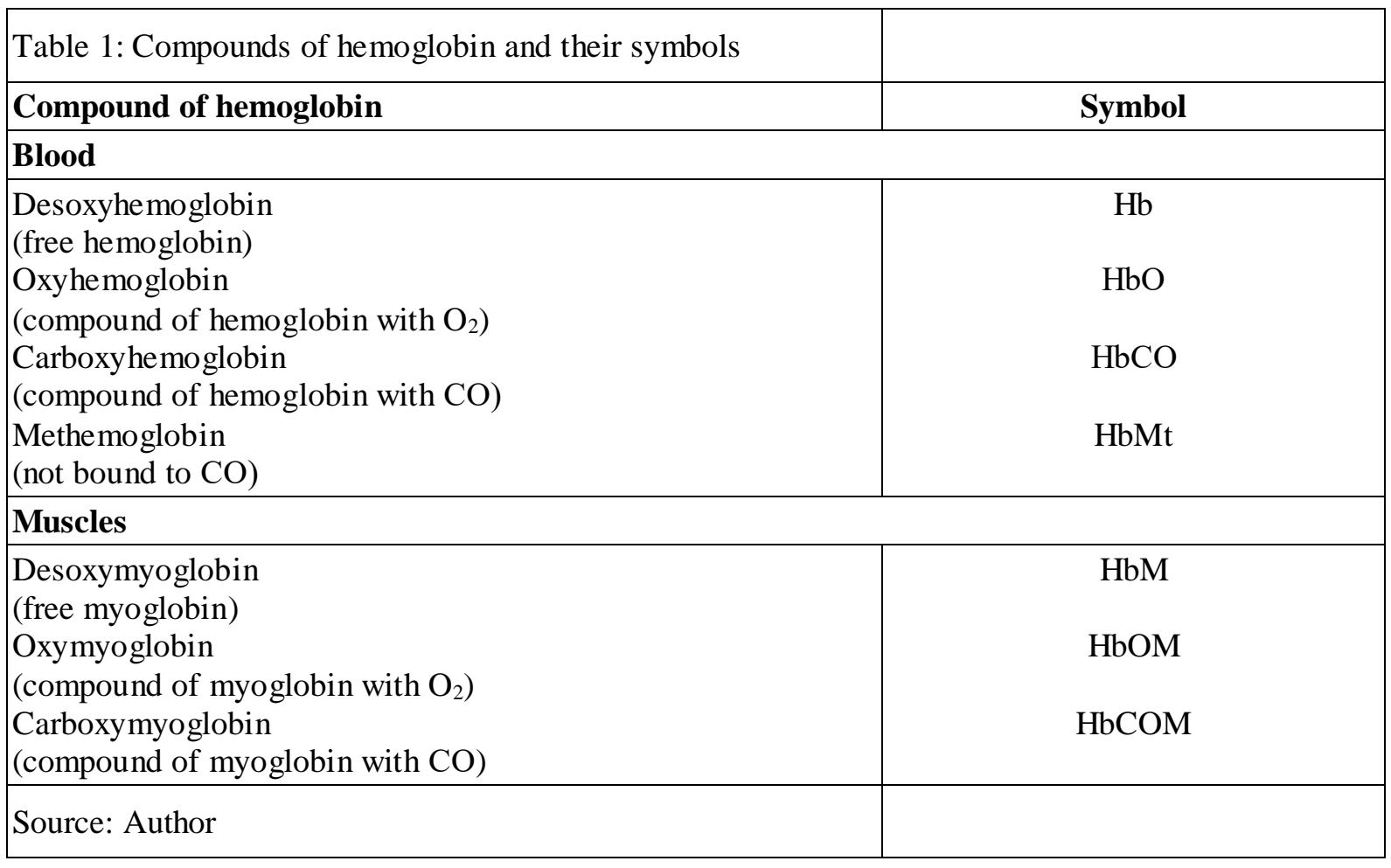

Carboxyhemoglobin $(\mathrm{HbCO})$ content in blood depends on the concentration of $\mathrm{CO}$ in the air, and the duration of the action on the body oxide. The greater the carboxyhemoglobin concentration in blood, the greater the $\mathrm{CO}$ partial pressure in the alveolar air with oxygen partial pressure. Symptoms of poisoning vary with different concentrations of $\mathrm{HbCO}$ in blood. The lethal proportion of $\mathrm{HbCO}$ in the blood is on average $60 \%$, but this can vary from 40 to $80 \%$. These variations depend on the influence of external conditions and the individual susceptibility.

\section{Methods}

The basic criteria and requirements in the higher medical institution for the specialist accreditation for Pharmacy, under conditions of the Bologna System in Ukraine, and according to instructions on quality assurance (ENQA), were: common demands for the concept of activity by declared specialty (specialization), agreed upon by City State Administration; staff provision for specialists' training by declared specialty; material and technical base; educational and instructional support; information support; and qualitative characteristics of specialists' training. The main methods used during the discipline studying were pedagogical, psychological, statistical, chemical, analytical, and biochemical.

The test control for basic topics contained questions related to general characteristics of poisons: objects of study, the ways of studied material isolation, general regularities of toxic dynamics and toxic kinetics, general methods of qualitative detection and quantitative definition, the scheme of metabolism on the phase I and II. The test control for specific topics contained questions related to each representative of the class. These were specific and additional objects of study, the ways of isolation, toxic dynamics, toxic kinetics, the methods of qualitative detection and quantitative 
definition, and the scheme of metabolism on the phases I and II. Herewith, especial attention was given to the complex approach in studying biotransformation of toxic substances in terms of biochemistry and toxicology. The students had the opportunity to work independently on the test control questions provided through the Internet, for tasks from the professor and in preparation for online activity. The results were assessed by standard methods of statistical analysis (Prozorovskiy, Prozorovskiy, \& Demchenko 1978; Sophyina, Sophyina, Goldin, \& Kmein, 1979; Belova, 1976).

\section{Results and Discussions}

It should be noted that in the literature, a previous schematic of these reactions had not been presented. The academic literature (Welchinska \& Nizhenkovska, 2015) for students of medical university described, for the first time, their proposed schemes for the processes of metabolism and reaction qualitative detection of carbon (II) monoxide. The main consideration of the material explored issues of metabolism and methods of qualitative and quantitative analysis of biological material for the content of carbon monoxide and its compound forms with hemoglobin. As previously mentioned, this poison is not isolated from biological material, and thus, it is necessary to analyze it directly in biological material (Lakin \& Krilov, 1981; Park, 1973).

The Metabolism of Carbon (II) Monoxide.

The toxic effect of $\mathrm{CO}$ is carried out by several mechanisms, which disrupt supply and uptake of oxygen in the tissue, and causes oxidative stress. In human blood, poisoned by $\mathrm{CO}$, hemoglobin is not completely converted to carboxyhemoglobin. Death occurs before it completes its transformation to a carboxyhemoglobin. A relatively large amount of hemoglobin in the blood (with mild poisoning) forms deoxy- or oxy-hemoglobin. Thus, high affinity binding of $\mathrm{CO}$ to hemoglobin results in: 1) the formation of carboxyhemoglobin, $\mathrm{HbCO} ; 2$ ) replacement of $\mathrm{O}_{2}$ in the hemoglobin molecule, reducing the transport of $\mathrm{O}_{2}$ in blood supply; 3 ) displacement of the dissociation curve of oxyhemoglobin, $\mathrm{HbO}$ left; 4) the ability to associate $\mathrm{CO}$ with other gem containing proteins (myoglobin and cytochromes), which play an important role in energy production by cells; and 5) the start by $\mathrm{CO}$ of cascade reactions, including brain lipid peroxidation, which leads to a temporary dysfunction and is irreversible. The above reactions are shown in Figure I.

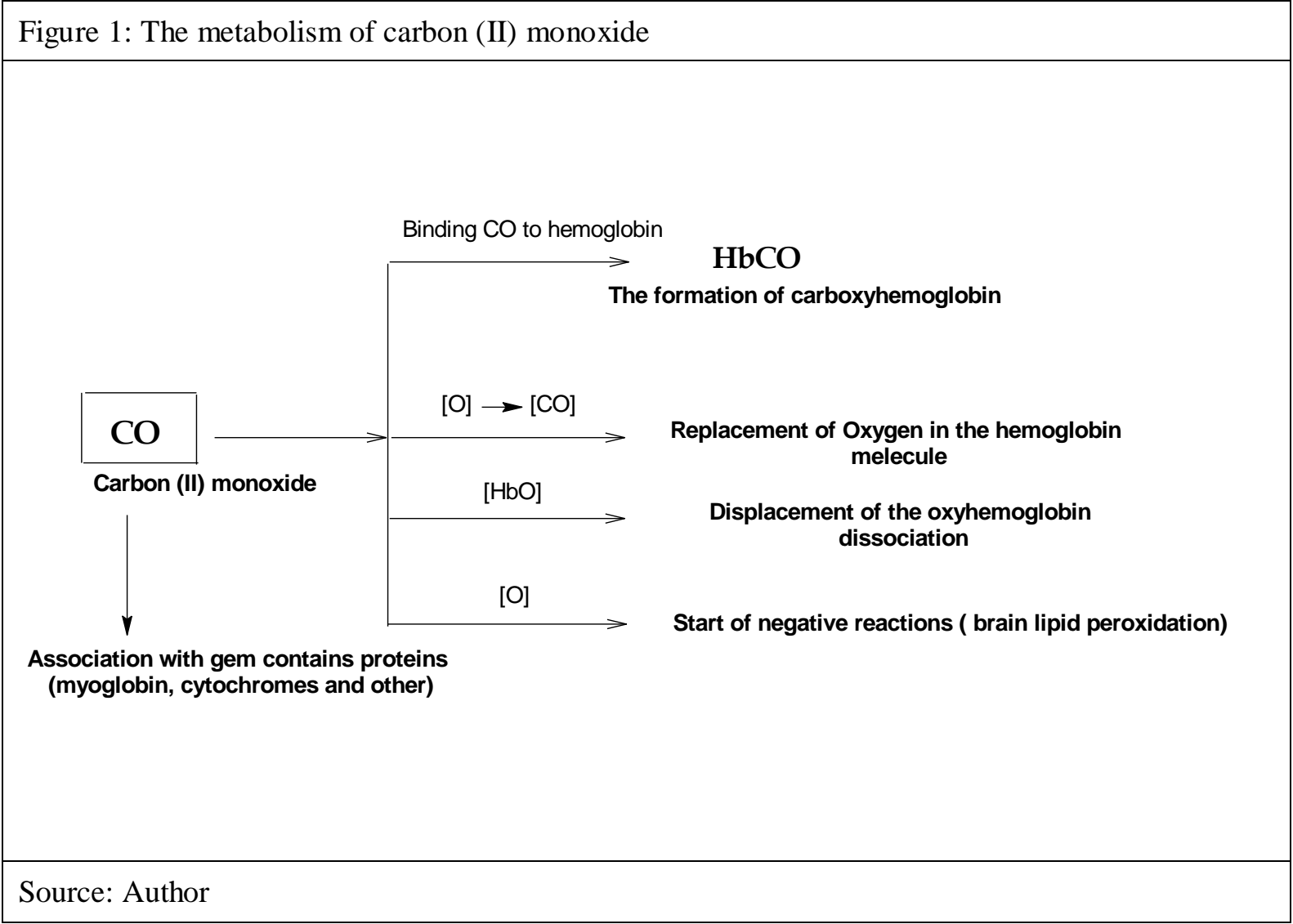




\section{Peculiarities of Isolation}

$\mathrm{CO}$ is determined directly in blood. Reactions in qualitative determination of carbon (II) monoxide include change the color of blood arising with the interaction of large amounts of desoxy- $(\mathrm{Hb})$ and oxyhemoglobin $(\mathrm{HbO})$ with reagents:

- the reaction with sodium hydroxide (Hoppe-Seylor test). Blood carboxyhemoglobin containing remains bright red, but blood without carboxyhemoglobin becomes brown:

$$
\mathrm{Hb}(\mathrm{HbO})+\mathrm{NaOH} \longrightarrow[\mathrm{Hb}(\mathrm{HbO}) \times \mathrm{NaOH}]
$$

\section{A brown colour}

- the reaction with ammonium sulfide (Salkovsky - Katayama test). Blood carboxyhemoglobin containing remains raspberry-red color, but blood without carboxyhemoglobin becomes graygreen:

$$
\mathrm{Hb}(\mathrm{HbO})+\left(\mathrm{NH}_{4}\right)_{2} \mathrm{~S} \longrightarrow\left[\mathrm{Hb}(\mathrm{HbO}) \times\left(\mathrm{NH}_{4}\right)_{2} \mathrm{~S}\right]
$$

\section{A gray-green colour}

- the reaction with quinine and ammonium sulfide (Horoshkevich-Marx test). Blood carboxyhemoglobin containing remains light pink color, but blood without carboxyhemoglobin becomes dirty red:

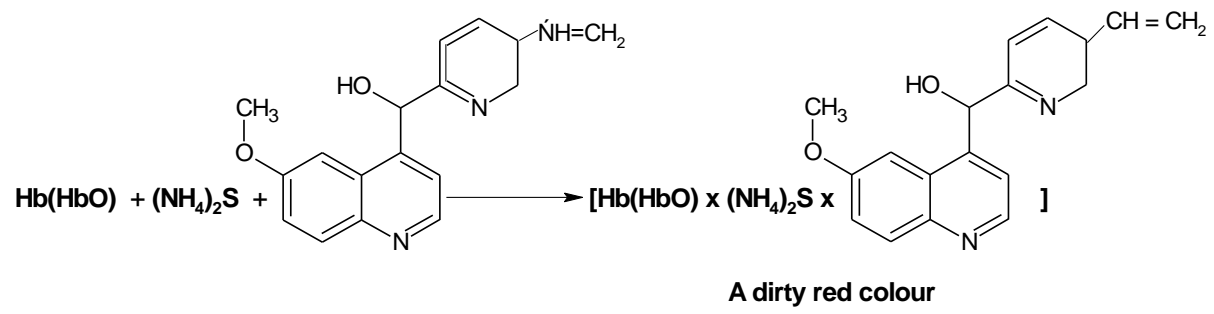

- the reaction with potassium (III) hexacyanoferrate (Burker test). Blood carboxyhemoglobin containing remains red color, but blood without carboxyhemoglobin becomes yellow:

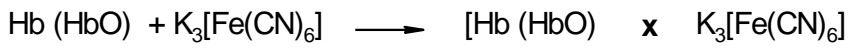

\section{An yellow colour}

- the reaction with potassium (III) hexacyanoferrate and potassium dichromate (Sidorov test). Blood carboxyhemoglobin containing remains carmine-red color, but blood without carboxyhemoglobin becomes brown-green:

$$
\mathrm{Hb}(\mathrm{HbO})+\mathrm{K}_{3}\left[\mathrm{Fe}(\mathrm{CN})_{6}+\mathrm{K}_{2} \mathrm{Cr}_{2} \mathrm{O}_{7} \longrightarrow\left[\mathrm{Hb}(\mathrm{HbO}) \times \mathrm{K}_{3}\left[\mathrm{Fe}(\mathrm{CN})_{6} \times \mathrm{K}_{2} \mathrm{Cr}_{2} \mathrm{O}_{7}\right]\right.\right.
$$

\section{A brown-green colour}

- the reaction with potassium (III) hexacyanoferrate and acetic acid (Wetzel test). From blood containing carboxyhemoglobin, falling cherry-red precipitate, and from blood without carboxyhemoglobin - gray-brown precipitate:

$$
\mathrm{Hb}(\mathrm{HbO})+\mathrm{K}_{3}\left[\mathrm{Fe}(\mathrm{CN})_{6}\right]+\mathrm{CH}_{3} \mathrm{COOH} \longrightarrow\left[\mathrm{Hb}(\mathrm{HbO}) \quad \mathbf{x} \quad \mathrm{K}_{3}\left[\mathrm{Fe}(\mathrm{CN})_{6} \quad \mathbf{x} \quad \mathrm{CH}_{3} \mathrm{COOH}\right]\right.
$$

\section{A gray-brown precipitate}

- the reaction with tannin (Kunkel-Wetzel test). From blood containing carboxyhemoglobin, falls carmine-red precipitate, and from blood without carboxyhemoglobin - gray-brown precipitate. Burker also suggested this reaction: according to his method, blood was diluted 100 times with water and, to $10 \mathrm{ml}$ of this solution, was added five drops of $3 \%$ of tannin solution: 


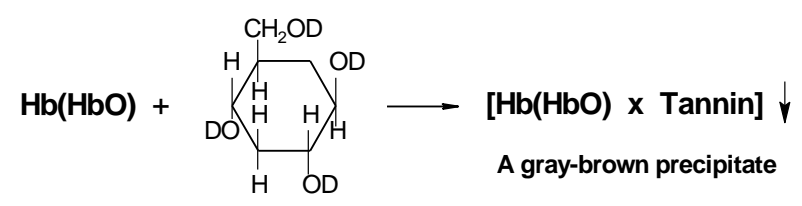

D - remiainder of gallic acid

- the reaction with formaldehyde (Libman test). Blood carboxyhemoglobin containing remains red color, but blood without carboxyhemoglobin becomes brown-black:

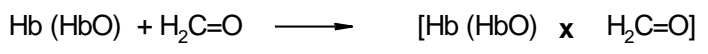

A brown-black colour

- the reaction with lead acetate (Rubner test). Blood carboxyhemoglobin containing remains red color, but blood without carboxyhemoglobin becomes brown:

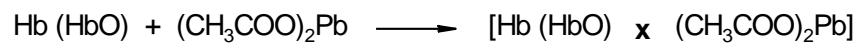

\section{A brown colour}

- the reaction with copper (II) sulfate (Zaleski test). Blood carboxyhemoglobin containing remains purple-red color, but blood without carboxyhemoglobin becomes green:

$$
\mathrm{Hb}(\mathrm{HbO})+\mathrm{CuSO}_{4} \longrightarrow\left[\begin{array}{ccc}
{[\mathrm{Hb}(\mathrm{HbO})} & \mathbf{x} & \mathrm{CuSO}_{4}
\end{array}\right]
$$

Quantitative determination of carbon (II) monoxide was performed by physical-chemical methods: gas chromatography (GC) and gas liquid chromatography (GLC), based on the height of the peak in the chromatogram of the compound; and the spectral (UV-spectrophotometry). All forms of hemoglobin $(\mathrm{Hb}, \mathrm{HbO}, \mathrm{HbCO}$, and $\mathrm{HbMt})$ can be determined from the absorption spectrums in the visible region in the wavelength range from 450 to $620 \mathrm{~nm}$. The absorption spectrums of oxyhemoglobin and carboxyhemoglobin are little different, so their spectral characteristics are not used for analytical purposes. Significantly different are absorption spectrums of desoxyhemoglobin and carboxyhemoglobin. A quantitative spectrophotometric determination of carbon (II) monoxide in blood preparing, include the next solutions: the study of blood; blood, containing a mixture of $(\mathrm{HbSO}$ $+\mathrm{Hb})$; and blood containing all forms of hemoglobin $(\mathrm{Hb}, \mathrm{HbO}$, and $\mathrm{HbMt})$, transferred in $\mathrm{HbCO}$ (Table 2).

Table 2: The spectral characteristics of the compounds of hemoglobin

\begin{tabular}{|l|l|c|}
\hline & Compound of hemoglobin & UV-spectrum \\
\hline 1. & Desoxyhemoglobin $(\mathrm{Hb})$ & $557 \mathrm{~nm}$ \\
\hline 2. & Carboxyhemoglobin $(\mathrm{HbCO})$ & $541 ; 571 \mathrm{~nm}$ \\
\hline Source: Author & \\
\hline
\end{tabular}

The test control for knowledge helps students realize the comprehensive and modern approach to the study of general theoretical and specific topics in the course, Toxicological chemistry that is the mainstay of providing high quality preparation of future pharmacists, according to the level of international requirements.

\section{Conclusion}

Thus, using lectures and practical training, a cascade of pedagogical and psychological methods, didactic material, and staged chemical experiments, can achieve a comprehensive and in-depth study of the topic. It is extremely important for reception imaging of biological and chemical processes to be 
used in studying the reaction schemes and biochemical transformations that allow students to better remember the material under study and present the processes. The study of each topic tested in the lab helped determine the extent and quality of the acquired material. At the end of the lecture, a short discussion is offered to answer questions about the topic studied.

\section{References}

Alexandrov, V. N., \& Emelianov, V. I. (1990). Yadovitie veschestva [Poison substances]. Moscow, M.: "Voenizdat". (In Russian).

Bayerman, K. (1987). Determination of minimal quantities of organic substances. Moscow, M.: “Mir”. (In Russian).

Belova, A.V. (1976). Praktikum k prakticheskim zaniytiym po toksikologicheskoy khimii [Instructions to practical trainings of toxicological chemistry]. Moscow, M.: "Medicine". (In Russian).

Busari, J., \& Arnold, A. E. R. (2009). Educating Doctors in the Clinical Workplace: Unraveling the Process of Teaching and Learning in the Medical Resident as Teacher. Journal of Postgraduate Medicine, 55(4), 278-283. doi: 10.4103/00223859.58935

Ellenhorn, M. J. (2003). Medicinskaya toksikologiya: Diagnostika i lechenie otravleniy tcheloveka [Medical toxicology: Diagnosis and treatment of human poisoning] (2-d ed.) (G.K. Faizova, Y.L. Amchenkova, S.B. Matveeva, S.V. Demicheva, Trans.): in 2 vol. Vol.2. Moscow, M.:"Medicine“". (Original work published 1995). (In Russian).

European Association for Quality Assurance in Higher Education. Helsinki, (2005).

Knunyants, I. L. (Ed.) (1992). Khimicheskaya enciklopediya [Chemical encyclopedia]: in 5 vol.: vol. 3 . Moscow, M.: "Big Russian encyclopedia“. (In Russian).

Communiqué of Conference European Ministers which responsible for higher education (2010). Komunike Konferencii Ministriv evropeyskih krain, vidpovidalnih za sferu vizhoi osvity Budapest - Vienna [Communique Conference Ministriv evropeyskih krain , vidpovidalnih for sphere vizhoi osvity Budapest - Vienna], 12 March 2010

Lakin, K. M., \& Krilov, Y. F. (1981). Biotransformatsiya meditcinskih veschestv [Biotransformation of medical substances] Moscow, M.: "Medicine". (In Russian).

Luznikov, E. A. (1994). Klinitcheskaya toksikologiya [Clinical toxicology]. Moscow, M.: "Medicine". (In Russian). Park, D. (1973). Biokhimiya ksenobiotikov [Biochemistry of xenobiotics]. Moscow, M.: "Medicine“. (In Russian).

Prozorovskiy, V. B., Prozorovskiy, V. P., \& Demchenko, V. M. (1978). Ekspress-metod opredeleniya sredney effektivnosty dozy i ego oshibka [Express - method of middle effective dose determination and its mistake]. Pharmacology and toxicology, 41(4), 407-509.

Sophyina, Z. P., Sophyina, A. B., Goldin, A., \& Kmein, A. (Eds.) (1979). Eksperimentalnaya otsenka protivoopuholevyh preparatov v SSSR i SShA [The experimental value of the antitumour drugs in USSR and USA]. Moscow, Russia: Medicine.

Welchinska, E. V., \& Nizhenkovska, I. V. (2015). Toksikologitcheskaya khimiya. Yadovitie veschestva I ih biotransformatsiya [Toxicological chemistry. Poisons and its biotransformation]. Kiev, K.: ID "ADEF-Ukraine". (In Russian). 